\title{
Quality Assessment of Commercially Produced Sandcrete Blocks in Okitipupa Local Government Area, Ondo State, Nigeria
}

\author{
A. J. Adese and O. D. Olajide
}

\begin{abstract}
The frequent collapse of buildings in Nigeria has necessitated carrying out a quality check not only on the structural design of these buildings but also on the materials used in their construction. Sandcrete blocks are used as a walling unit mostly because they are cheap and fast to produce. They can also be use as either load-bearing or non-load bearing purpose. Hence, this paper gives an in-depth quality assessment of sandcrete blocks commercially produced in Okitipupa Local Government Area of Ondo State, Nigeria. Six sandcrete block producing locations were visited within the local government and both six inches $\left(6^{\prime \prime}\right)$ blocks $(450 \times 150 \times 225 \mathrm{~mm})$ and nine inches $\left(9^{\prime \prime}\right)$ blocks $(450 \times 225 \times 225 \mathrm{~mm})$ from each location were randomly collected, together with their soil samples. Twenty-four control samples of 6" and 9" sandcrete blocks were also produced in accordance with the Nigerian Industrial Standard (NIS 87: 2007). Specific gravity test, silt/clay content and sieve analysis test were performed on each soil samples from different locations to check their suitability for block production, in addition, bulk density, compressive strength and water absorption were performed on the collected sandcrete blocks. In general, the compressive strength of the block samples was between $1.09 \mathrm{~N} / \mathrm{mm}^{2}$ to $1.19 \mathrm{~N} / \mathrm{mm}^{2}$ for six inches and $1.37 \mathrm{~N} / \mathrm{mm}^{2}$ to $1.64 \mathrm{~N} / \mathrm{mm}^{2}$ for nine inches which falls below the $2.5 \mathrm{~N} / \mathrm{mm}^{2}$ and $3.45 \mathrm{~N} / \mathrm{mm}^{2}$ minimum recommendation given by the NIS.
\end{abstract}

Keywords - compressive strength, Sandcrete block, sieve analysis, quality.

\section{INTRODUCTION}

Sandcrete blocks are the most frequently used materials as far as building construction is concerned in Nigeria. Hence, the assessment of its strength should be of priority to contractors, manufacturers, and the different personnel involved in its production and usage. Its low production cost, maintenance, resistance to fire, durability, and ease of usage as a partition element and walling units can be said to be the reason for its vast usage [1], [2], they neither decay nor exhibit harmful substance that is dangerous to the surroundings [3]. Significantly high number of buildings are being built in Nigeria with sandcrete blocks and other West African countries [4], [5]. For some years now in Nigeria, there have been issue of building failure with a lot of criticism among the professionals in the built industry. According to [6], this problem persists because of the sub-standard materials been

Submitted on November 11, 2021.

Published on December 02, 2021.

A. J. Adese, Civil Engineer, Nigeria.

(e-mail: adeseakorede@gmail.com) used while [7] also attest to this in the research he carried out on residential facilities by Public-Private-Partnership (PPP) In Ogun State.

However, due to the frequent collapse of building in Nigeria, the Nigeria Industrial Standard (NIS) came up with a reference document in the year 2000 (NIS 87:2000) to regularize the production and use of sandcrete blocks. The standard stipulates procedures to follow in acquiring materials, quality control during production and testing of the final products. The standard also includes the minimum requirements for various tests towards attaining a safe and durable sandcrete block. The latest review was in 2007 which resulted to the publication of a new standard NIS 87: 2007 that specified 1:8 mix ratio and 0.45 water to cementitious material $(w / c)$ to achieve the minimum recommended compressive strength of $2.5 \mathrm{~N} / \mathrm{mm}^{2}$ for non-load bearing or $3.5 \mathrm{~N} / \mathrm{mm}^{2}$ for load-bearing sandcrete blocks.

According to [8], majority of the sandcrete blocks in circulation in Nigeria are below the standard given by NIS 87 : 2007. Furthermore, [9] reported from the study carried out that the use of such blocks has resulted to as many as 56 cases of collapse of buildings in Lagos State between the year 2000 to 2010 which has also resulted to several loss of properties and lives. Also, [10] reported that substandard materials used during construction such as bricks and blocks plays a huge role in building collapse. Similar claims were made by [11] after assessing the properties of the produced sandcrete blocks in Gombe metropolis. The genesis of the collapse of buildings has previously been attributed to failed reinforced structure elements. However, other building members could cause equal risk or contributes to the loss of the building serviceability. [12] opined that some of the problem of building collapse in the country is largely due to poor sandcrete block quality used in construction. [13] observed that sandcrete blocks quality differs in location owing to production difference and material properties. [14] also studied the quality control measures put in place during sandcrete block production in Yewa South of Ogun State, Nigeria. He concluded that almost all commercial block producers are ignorant of any standard or relevant code regarding block production quality. He further stated that the low blocks quality was due to not adhering to the standardized

O. D. Olajide, Department of Building, Civil and Environmental Engineering, Concordia University, Montreal, Canada.

(e-mail: olusola.olajide@concordia.ca) 
procedures and quality control. Therefore, the result of the quality assessment of sandcrete blocks produced from six industrial locations as shown in Fig. 1 within Okitipupa LGA of Ondo State is presented in this paper.

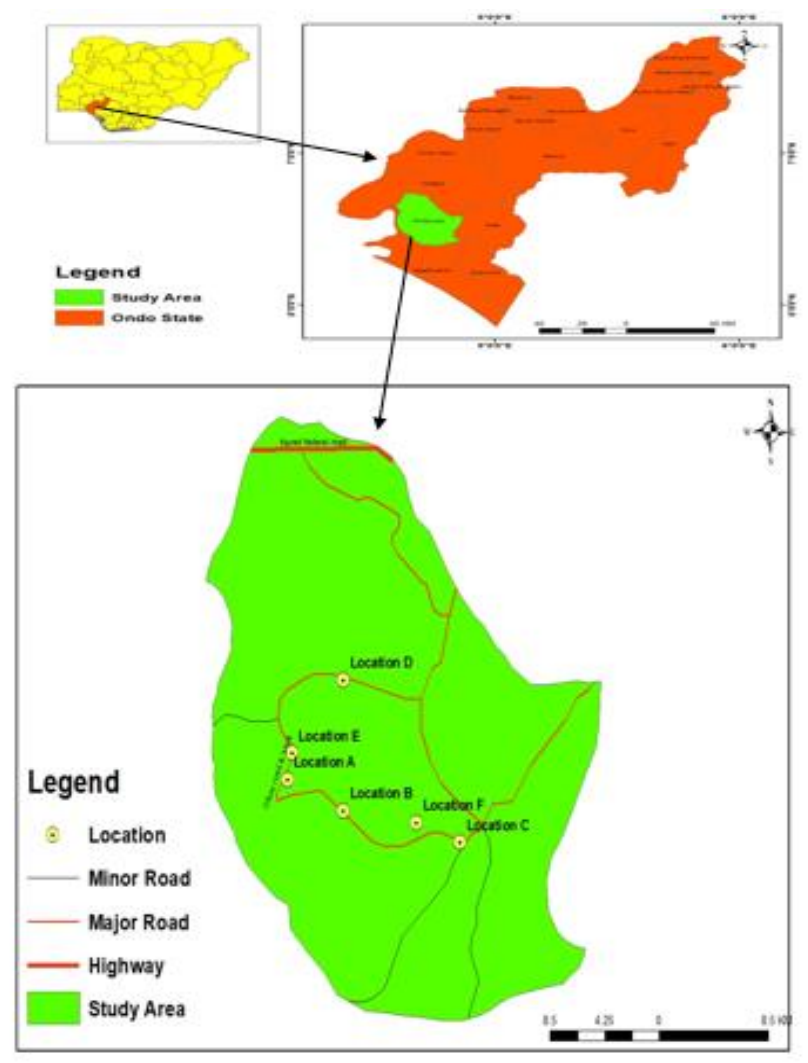

Fig. 1. Study Area.

\section{Methodology}

Six different block producing sites were visited in Okitipupa LGA to ascertain the physio-mechanical properties of sandcretes blocks produced within the local government. The methods adopted in carrying out this research include field survey, observation, and where appropriate, questions were asked about the quality assurance and production process which include mix ratio, mixing method, mode of compaction, curing days, blocks produced per bag, cement brand, and source of water used during production as shown in Table I. Also, representative samples were collected for various laboratory tests. Three pieces of both six (6") inches and nine $\left(9^{\prime \prime}\right)$ inches sandcrete block specimen was taken from each location together with the sand used in their production. Sand, cement and water were the constituent of the block produced from the six locations. Two mix ratios (1:12 and 1:10) were observed to be majorly used in all the locations.

In addition, the Dangote brand of ordinary Portland cement of grade 32.5 was seen to be used with borehole serving as their main source of water for mixing and curing. The curing days vary from one location to the other while the blocks produced per bag seem to be relatively uniform. For most locations, forty blocks were produced per bag for six inches block except in locations $\mathrm{A}$ and $\mathrm{C}$ while thirty-five blocks were common for nine inches blocks. However, all the locations used the same method of production, curing, water source, and cement type. Control samples which comprise of 6" and 9" sandcrete blocks were produced using a mix ration of 1:6 and water to cement ratio of 0.45 as required by NIS standard.

Laboratory tests such as sieve analysis, specific gravity, organic content, and silt-clay content were performed on the sand used to ascertain its suitability for block production, likewise, compressive strength, bulk density, and water absorption of the block samples were also determined to check their conformance with the recommendation given by NIS: 2007. Particle size distribution was carried out on the sand used in each location to evaluate the size range of particles present; it was done in compliance with [15]. The coefficient of uniformity $(\mathrm{Cu})$ and coefficient of curvature $(\mathrm{Cc})$ were calculated to determine the gradation of the soil sample and the results were compared with published limits. The specific gravity test was done to examine the void in the soil samples. Also, the silt/clay content was carried out following [16] to examine the bonding capacity which in turn affects the strength and durability of the block produced. In other to determine their behaviour under loading, the block samples were subjected to compressive loading. Finally, bulk density and water absorption were performed on the block samples in compliance to [17] and [18] respectively.

$\mathrm{C}_{u}=\frac{\mathrm{D}_{60}}{\mathrm{D}_{10}}$

$C_{c}=\frac{\left(D_{30}\right)^{2}}{D_{60} \times D_{10}}$

$\mathrm{D}_{60}=$ diameter of soil particles for which $60 \%$ are finer and $40 \%$ are coarse;

$\mathrm{D}_{30}=$ diameter of soil particles for which $30 \%$ are finer and $70 \%$ are coarse;

$\mathrm{D}_{10}=$ diameter of soil particles for which $10 \%$ are finer and $90 \%$ are coarse.

TABLE I: SUMMARY OF FIELDS SURVEY AND QUESTIONNAIRE

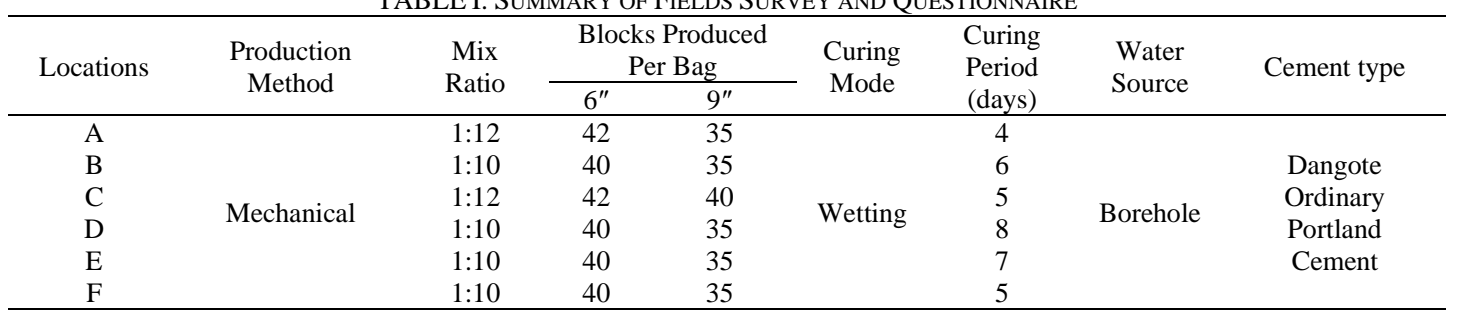




\section{RESULT AND DISCUSSION}

\section{A. Particle Size Distribution}

The distribution curve of the sieve analysis test carried out on the collected soil samples from each location and that of the control are presented in Fig. 2 below while Table II shows their respective grade when their $\mathrm{C}_{\mathrm{c}}$ and $\mathrm{C}_{\mathrm{u}}$ values are computed.

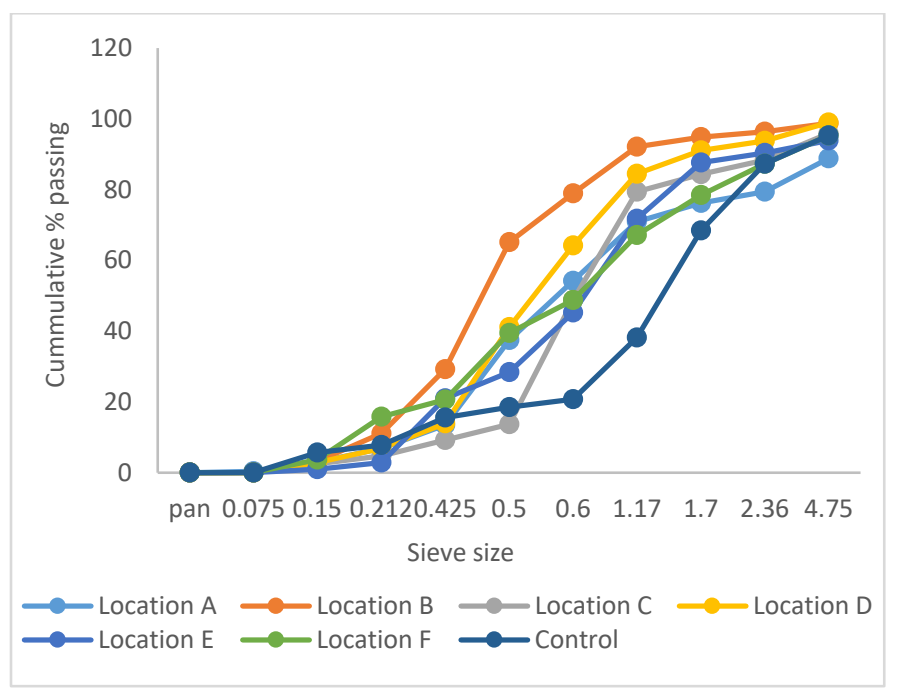

Fig. 2. Particle distribution curve for each location.

All the samples were poorly graded and only the control sample is well graded. This can affect the compaction rate of the block samples, thus, creating more voids which increases permeability and could lead to strength reduction in the blocks.

\begin{tabular}{ccccc}
\multicolumn{6}{c}{ TABLE II: SAND SAMPLES ClassifICATION BASE ON THEIR CU AND CC } \\
\multicolumn{5}{c}{ VALUES } \\
\hline Specimen & $\mathrm{Cu}$ & $\mathrm{Cc}$ & Grading & $\begin{array}{c}\text { Condition for a well-graded } \\
\text { sand }\end{array}$ \\
\hline $\mathrm{A}$ & 2.00 & 1.02 & Poorly graded & \\
$\mathrm{B}$ & 2.50 & 2.03 & Poorly graded & \\
$\mathrm{C}$ & 1.56 & 0.79 & Poorly graded & $\mathrm{Cu} \geq 4 ; 1 \leq \mathrm{Cc} \leq 3$ \\
$\mathrm{D}$ & 1.79 & 1.28 & Poorly graded & \\
$\mathrm{E}$ & 3.10 & 0.96 & Poorly graded & \\
F & 3.91 & 1.11 & Poorly graded & \\
Control & 6.07 & 1.70 & Well graded & \\
\hline
\end{tabular}

\section{B. Silt/Clay Content Test}

The silt-slay content test result performed on the sand samples used for the block production is presented in Fig. 3 below.

Sand sample whose ratio of silt-clay content to sand exceeds the recommendation given by BS 8821992 (i.e., 8\%) were observed in samples from locations $\mathrm{A}$ and $\mathrm{C}$ with 8.7 and 9.25 percent respectively. The presence of silt/clay content in high percentage tends to increase the affinity for water, hence, increases the evaporation rate [19] which eventually leads to low strength sandcrete blocks. In addition, Local stress which affects shrinkage cracking also increases because of the expansion of clay on absorbing water as stated in [20].

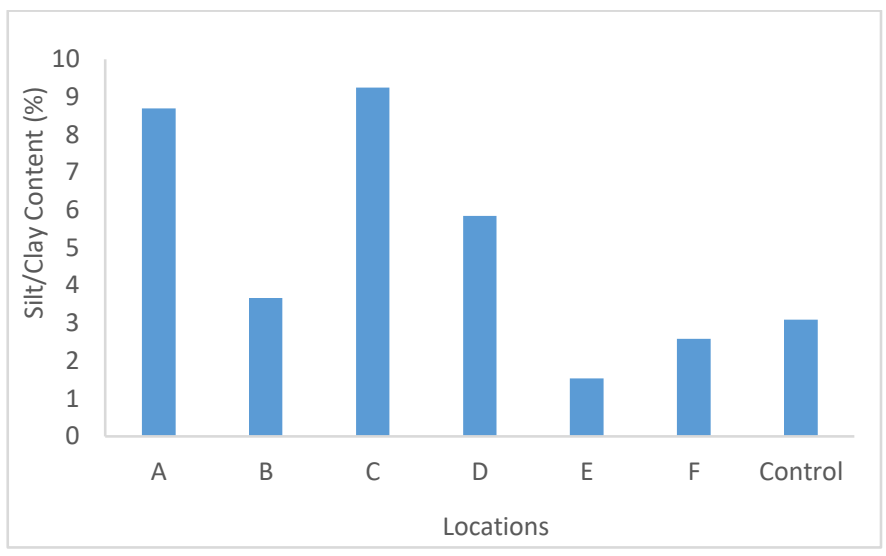

Fig 3: Silt-clay percentage distribution.

\section{Specific Gravity}

Specific gravity (Gs) tests conducted on the sand sample is presented in Figure 4. A higher value of specific gravity to a certain extent is directly related to the strength of sandcrete block produced from the aggregates. The specific gravity test carried out on the sand samples tends to be in agreement with this relationship. Samples from location A, C, and D is said to have more coarse particles because of their low specific gravity while the sample from location B, E, F, and the control have a relatively high specific gravity which means their particles are finer.

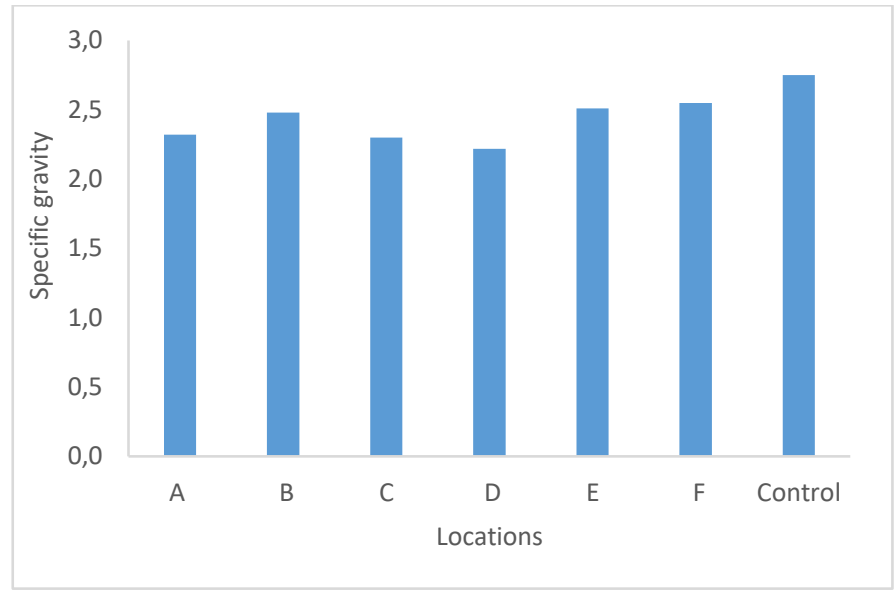

Fig. 4. Specific gravity test results.

\section{Water Absorption}

The rate of water absorption is presented in Fig. 5. After immersing the block samples in water for 24 hours, the results reveal that most of the blocks have a percentage absorption rate higher than the recommendation given in NIS 87: 2007 (maximum rate of water absorption $12 \%$ ). It could be due to poor mix ratio, inadequate curing, or improper compaction during production. Such blocks are prone to rapid ingress of water. However, the water absorption for the control samples decreases with increase in curing days with values within the recommendation as seen in Fig. 6. 


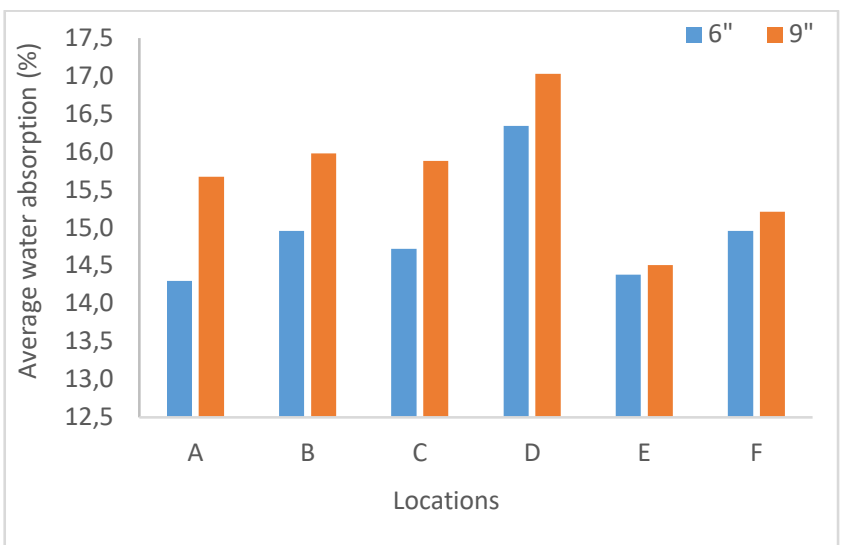

Fig. 5. Average water absorption test results.

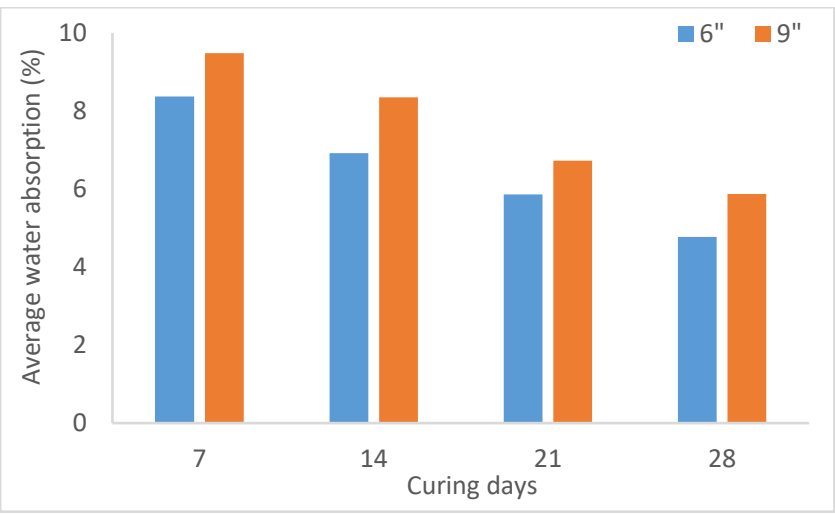

Fig. 6. Average water absorption for control samples.

\section{E. Bulk Density}

Dry density tests were performed on the block samples from the various locations and their results are presented in Fig. 7. The calculated volumes for six and nine-inches blocks were $0.0079 \mathrm{~mm}^{3}$ and $0.0102 \mathrm{~mm}^{3}$, respectively. From the result, most of the block samples were below the recommendation given in BS EN 1097 minimum limit of $1920 \mathrm{~kg} / \mathrm{m}^{3}$ for individual blocks and $2020 \mathrm{~kg} / \mathrm{m}^{3}$ for an average of three (3) blocks. The highest blocks samples are from location $\mathrm{E}$ with $2084.39 \mathrm{~kg} / \mathrm{mm}^{3}$ and $2071.90 \mathrm{~kg} / \mathrm{mm}^{3}$ for six and nine inches blocks, respectively. As presented in Fig. 8, the control samples exhibit a bulk density above the recommended values for individual and average of three blocks for curing day 7,14,21 and 28 .

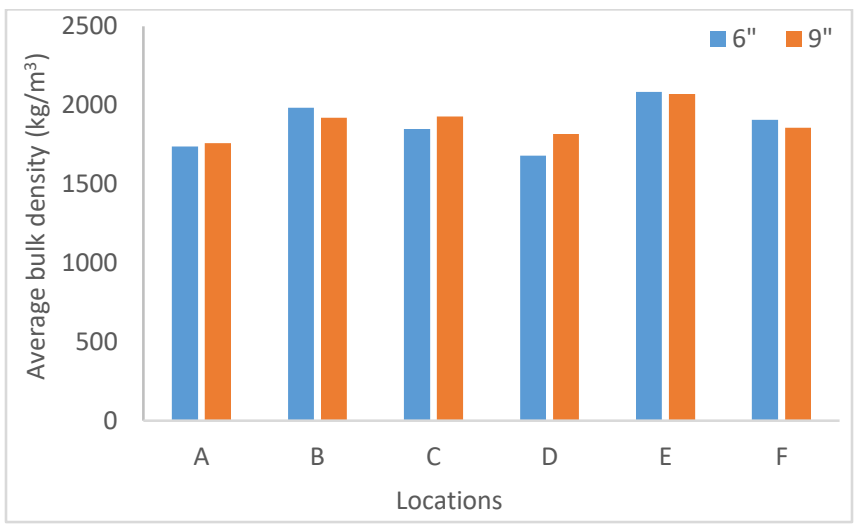

Fig. 7. Average bulk density results.

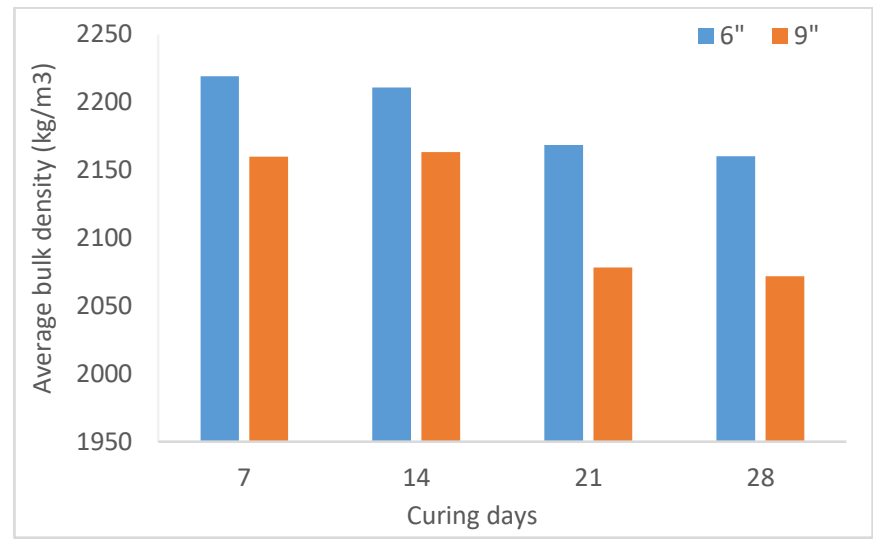

Fig. 8. Average bulk density for control samples.

\section{F. Compressive Strength}

The compressive strength of the block samples is presented in Fig. 9. The loaded area for six inches blocks was $52500 \mathrm{~mm}^{2}$ and $63750 \mathrm{~mm}^{2}$ for nine inches. The values of the compressive strength obtained from all the locations were below than the $2.5 \mathrm{~N} / \mathrm{mm}^{2}$ and $3.5 \mathrm{~N} / \mathrm{mm}^{2}$ recommendation given by NIS 87 : 2007 for non-load and load-bearing block. Block samples with the highest strength were from location $\mathrm{E}$ for nine inches with a percentage reduction of $53.14 \%$ in strength when compared with the recommended standard while location A gave the highest strength for six inches with a $52.40 \%$ reduction in strength. The observation from the compressive strength of the control given in Fig. 10 is that at 21 days of curing, the blocks attained the recommended value given by NIS. Further curing of the blocks till 28 days has an increase of $15.71 \%$ and $24.8 \%$ in strength for six and nine inches respectively when compared with the recommended values.

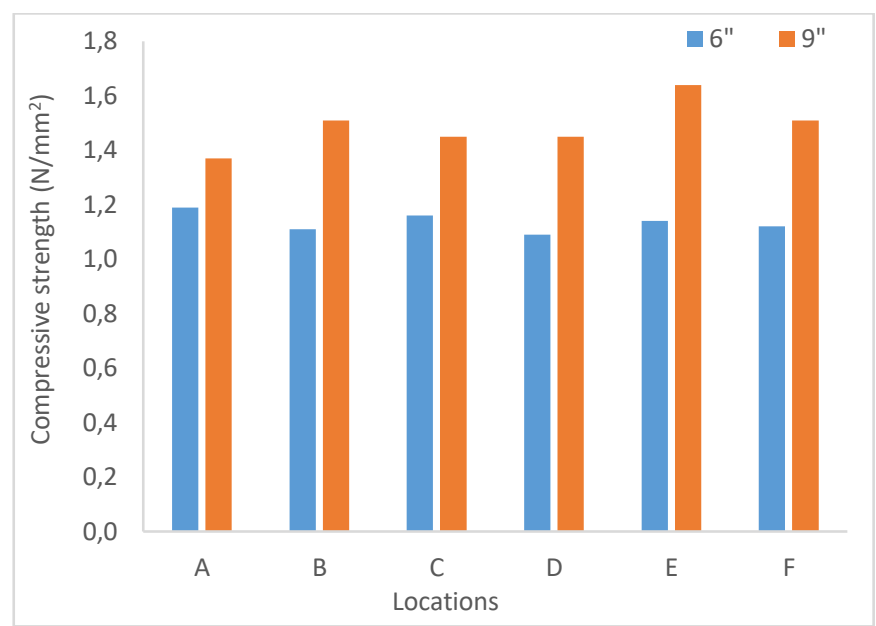

Fig. 9. Compressive strength test results. 


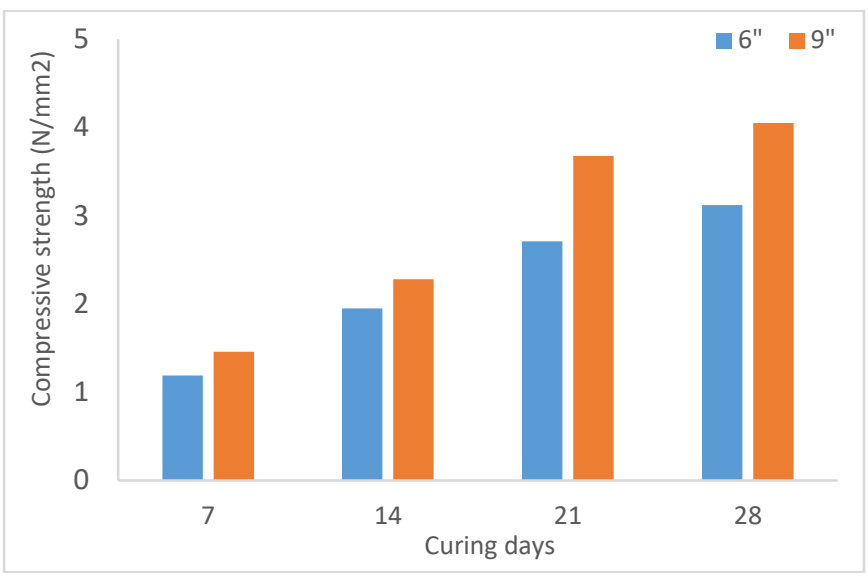

Fig. 9. Compressive strength of the control samples.

\section{CONCLUSION AND RECOMMENDATION}

This study has shown that the conformity and the standard of produced sandcrete block in circulation in Okitipupa Local Government Area of Ondo State, Nigeria is very low with a high degree of variability when compared with the recommendation given by the NIS 87: 2007. From the tests performed on the collected samples in various locations within the local government and comparing the result with the control samples, it can be said that the low quality of sandcrete blocks were as a result of the quality of sand used, poor compaction, and inadequate curing. Also, little or no knowledge of the producer can also be added to it. The silt/clay content and the soil gradation test performed on all the soil samples clearly show that the soil samples used are not appropriate for block production. Likewise, the rate of water absorption, dry density, and the compressive strength of the produced blocks show that they are below the specified standard given by NIS 87: 2007.

On the basis of the conclusion given above, required regulatory bodies such as the Nigeria Institute of Standard (NIS) and Standard Organization of Nigeria (SON) should be empowered to sanction any block producer that does not follow the recommendation given in NIS 27: 2007. In addition, block producers should be regulated and licensed, such that only those that have the capacity to produce quality blocks are given access to production.

\section{REFERENCES}

[1] Ajao A. M., Ogunbayo B. F., Ogundipe K. E., Bamigboye G., Ogunde A., \& Tunji-Olayeni P. F. Assessment of sandcrete blocks manufacturers compliance to minimum standard requirements by standard organization of Nigeria in Southwest, Nigeria. International Journal of Applied Engineering Research, 2018; 13(6), 4162-4172.

[2] Ojo O. J. Practices of small-scale of sandcrete block manufacturers in Osun State, Nigeria. FUTA Journal of Management and Technology, 2016; 1(2), 62-68.

[3] Ambrose E. E., Etim R. K., Koffi N. E. Quality assessment of commercially produced sandcrete blocks in part of Akwa Ibom State, Nigeria. Nigerian Journal of Technology (NIJOTECH), 2019; 38(3), 586-593.

[4] Anosike M. N. and Oyebade A. A. Sandcrete blocks and quality management in Nigeria building industry. Journal of Engineering, Project and Production Management, 2012; 2(1):37-46.
[5] Oladeji O. S., and Awos O. A. Assessment of materials and process variables on regulatory compliance of sandcrete blocks: a case study of Ogbomoso, Nigeria. Intl. Journal of Engineering Research and Applications, 2013; 3(6), 793-799.

[6] Onwuka D. O., Osadebe N. N., and Okere C. E. Structural characteristics of sandcrete blocks produced in South-East Nigeria. Journal of Innovative Research in Engineering and Sciences, 2013; 4(3), 483- 490.

[7] Ogunbayo B. F., Ajao A. M., Alagbe O. T., Ogundipe K. E., TunjiOlayeni P. F., and Ogunde A. O. Residents' facilities satisfaction in housing project delivered by public-private-partnership (PPP) in Ogun State, Nigeria. International Journal of Civil Engineering and Technology, 2018; 9(1), 562-577.

[8] Alohan O. Impact of vibration time on compressive strength of hardened sandcrete building blocks. Buildings journal, 2012; 2, 153-172. doi: 10.3390/buildings 2020153

[9] Ayedun C. A., Durodola O. D., and Akinjare O. A. An empirical ascertainment of the causes of building failure and collapse in Nigeria. Mediterranean Journal of Social Sciences, 2010; 3(1), 313-322.

[10] Sholanke A. B., Fagbenle O. O., Aderonmu A. P. Ajagbe M. A. Sandcrete block and brick production in Nigeria - prospects and challenges. International Journal of Environment Research, 2015; 1(4), 1-17.

[11] Akeeem U., and Umar G. Quality assurance of hollow sandcrete blocks produced by block moulding factories in Gombe Metropolis. Journal of Science, Technology \& Education, 2013; 2(1), 61-65.

[12] Ewa D. E., and Ukpata J. O. Investigation of the compressive strengths of commercial sandcrete blocks in Calabar Nigeria. International Journal of Engineering and Technology, 2013; 3(4) 477-482.

[13] Awolusi I., Aliu S., Oyeyipo O. An assessment of the quality of sanscrete blocks used for construction in Lagos Metropolis. CIB W107 International Conference, pp 562-571, 2014

[14] Omopariola S. S. An appraisal of the quality control practices in sandcrete blocks production in Yewa South Area of Ogun State, Nigeria. American Journal of Engineering Research, AJER, 2014; 3(4), 01-07.

[15] BS 812, 1991. Testing aggregates, Part 104: Methods for determination of particle size distribution - Section 103.1 Sieve tests. BSI, London.

[16] BS 882, 1992.Specification for aggregates from natural sources for concrete. British Standards Institutions. 2 Park Street, London.

[17] BS EN 1097-3: 1998 Tests for mechanical and physical properties of aggregates. Determination of loose bulk density and voids.

[18] BS 1377, 1990. Methods of test for soils for civil engineering purposes. British Standards Institutions. 2 Park Street, London.

[19] A. M. Neville, Properties of Concrete. $4^{\text {th }}$ Edition, Pearson, England. Pp $137-138,2000$.

[20] BS EN 1008, 2nd Edition, June 18, 2021 - Mixing Water for Concrete Specification for Sampling, Testing and Assessing the Suitability of Water, Including Water Recovered from Processes in the Concrete Industry, as Mixing Water for Concrete.

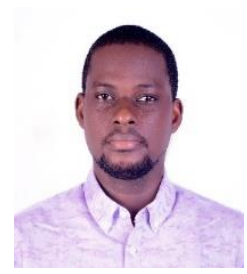

Adese Akorede John graduated with M.Eng. honours in Civil Engineering with specialization in Structural Engineering from the Federal University of Technology Akure, Nigeria, and also bagged a B.Eng in Civil Engineering from the same school. He is a registered and practicing engineer who has worked on several construction projects.

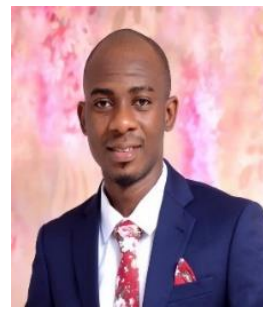

Olajide Olusola David is a Ph.D. candidate at the Department of Building, Civil and Environmental Engineering, Concordia University, Montreal, Canada. He had his bachelor's degree in civil engineering from the Federal University of Technology Akure (FUTA), Nigeria. Olusola's research is focused on the performance of concrete materials. He has been involved in projects assessing the influence of deterioration mechanisms like Alkali-Silica Reaction, Freezing and Thawing, and Corrosion on the performance of concrete. 